\title{
Cytotoxicity of Brazilian plant extracts against oral microorganisms of interest to dentistry
}

Jonatas Rafael de Oliveira ${ }^{1 *}$, Vinicius Carlos de Castro ${ }^{1}$, Polyana das Graças Figueiredo Vilela', Samira Esteves Afonso Camargo ${ }^{2}$, Cláudio Antonio Talge Carvalho ${ }^{3}$, Antonio Olavo Cardoso Jorge ${ }^{1}$ and Luciane Dias de Oliveira²

\begin{abstract}
Background: With the emergence of strains resistant to conventional antibiotics, it is important to carry studies using alternative methods to control these microorganisms causing important infections, such as the use of products of plant origin that has demonstrated effective antimicrobial activity besides biocompatibility. Therefore, this study aimed to evaluate the antimicrobial activity of plant extracts of Equisetum arvense L., Glycyrrhiza glabra L., Punica granatum L. and Stryphnodendron barbatimam Mart. against Staphylococcus aureus, Staphylococcus epidermidis, Streptococcus mutans, Candida albicans, Candida tropicalis, and Candida glabrata, and to analyze the cytotoxicity of these extracts in cultured murine macrophages (RAW 264.7).

Methods: Antimicrobial activity of plant extracts was evaluated by microdilution method based on Clinical and Laboratory Standards Institute (CLSI), M7-A6 and M27-A2 standards. The cytotoxicity of concentrations that eliminated the microorganisms was evaluated by MTT colorimetric method and by quantification of proinflammatory cytokines (IL-1 $\beta$ and TNF-a) using ELISA.

Results: In determining the minimum microbicidal concentration, E. arvense L., P. granatum L., and S. barbatimam Mart. extracts at a concentration of $50 \mathrm{mg} / \mathrm{mL}$ and G. glabra L. extract at a concentration of $100 \mathrm{mg} / \mathrm{mL}$, were effective against all microorganisms tested. Regarding cell viability, values were $48 \%$ for $E$. arvense $L$., $76 \%$ for $P$. granatum $L, 86 \%$ for S. barbatimam Mart. and $79 \%$ for $G$. glabra L. at the same concentrations. About cytokine production after stimulation with the most effective concentrations of the extracts, there was a significant increase of IL-1 $\beta$ in macrophage cultures treated with S. barbatimam Mart. (3.98 pg/mL) and P. granatum L. ( $7.72 \mathrm{pg} / \mathrm{mL})$ compared to control $(2.20 \mathrm{pg} / \mathrm{mL})$ and a significant decrease of TNF-a was observed in cultures treated with G. glabra L. (4.92 pg/mL), S. barbatimam Mart. $(0.85 \mathrm{pg} / \mathrm{mL})$, E. arvense L. $(0.83 \mathrm{pg} / \mathrm{mL})$, and P. granatum L. $(0.00 \mathrm{pg} / \mathrm{mL})$ when compared to control $(41.96 \mathrm{pg} / \mathrm{mL})$.
\end{abstract}

Conclusions: All plant extracts were effective against the microorganisms tested. The G. glabra L. extract exhibited least cytotoxicity and the E. arvense L. extract was the most cytotoxic.

Keywords: Equisetum arvense L, Glycyrrhiza glabra L, Punica granatum L, Stryphnodendron barbatimam Mart, Staphylococcus aureus, Staphylococcus epidermidis, Streptococcus mutans, Candida albicans, Candida tropicalis, Candida glabrata

\footnotetext{
* Correspondence: jroliveira16@hotmail.com

${ }^{1}$ Department of Biosciences and Oral Diagnosis, Laboratory of Microbiology

and Immunology, Institute of Science and Technology, Univ Estadual

Paulista/UNESP, Av. Engenheiro Francisco José Longo, 777 - Jardim São

Dimas, São José dos Campos, SP, Brazil

Full list of author information is available at the end of the article
} 


\section{Background}

Herbal drugs have been used since ancient times as remedies for the treatment of a variety of diseases. Despite advances in modern medicine, plants still make an important contribution to health care [1]. Herbal extracts or essential oils prepared from medicinal plants contain different compounds with numerous biological activities confirmed by in vitro and in vivo studies, such as antibacterial, antifungal, antiviral, antiprotozoal, anthelminthic, antiseptic, anti-inflammatory, antitumor, antioxidative, antiallergic, anticonvulsant, antidepressant, contraceptive, antimutagenic, analgesic, and diuretic properties [2-4]. Some compounds are used for the treatment of diabetes, nervous system disorders such as Alzheimer's disease, dental diseases, male infertility, and erectile dysfunction [5], among other therapeutic properties.

Studies have demonstrated the antimicrobial activity of Equisetum arvense L. (Equisetaceae), Glycyrrhiza glabra L. (Fabaceae), Punica granatum L. (Punicaceae), and Stryphnodendron barbatimam Mart. (Leguminosae) [6-11]. However, knowledge of the toxicity of these extracts is scarce. Scientific knowledge of the antimicrobial properties of plant species may contribute to the development of drugs against microorganisms of medical interest, particularly in dentistry. In this respect, the environmental conditions of the oral cavity favor infection and inflammation caused by opportunistic microorganisms such as Staphylococcus spp., Streptococcus spp., and Candida spp.

Staphylococcus aureus can cause endodontic infections, parotid gland infections, mandibular osteomyelitis, mucositis, apical abscesses, and postoperative complications after dental implant placement [12-14]. Moreover, methicillin-resistant $S$. aureus (MRSA) have emerged as causative agents of serious infections in hospitals [15].

Staphylococcus epidermidis is an important agent of hospital-acquired infections and possesses pathogenic properties such as adhesion to implanted materials and biofilm formation [16]. Microorganisms organized in biofilms are more resistant to antimicrobial agents and components of host immunity $[17,18]$.

Streptococcus mutans is an important etiological agent of dental caries in humans that attaches to the tooth surface and forms a biofilm $[13,14]$. For this purpose, the microorganism produces glucosyltransferases and synthesizes an adherent and water-insoluble glucan from sucrose that permits it to adhere firmly to the tooth surface [19]. The colonization of the oral cavity with $S$. mutans depends on factors such as salivary flow, saliva buffering capacity, and presence of salivary immunoglobulins [20].

Biofilm formation is an important virulence factor for Candida species because it increases resistance to antifungal therapy [21,22]. C. albicans is the most pathogenic species in humans and is commonly identified in dental prostheses and oral candidiasis. These yeasts colonize the oral mucosa, tongue and palate. Oral, vaginal or systemic candidiasis is a common infection in immunocompromised patients that can be fatal $[13,14,21,23,24]$.

Alternative microbiological control measures that are suitable for use in humans are of the utmost importance in view of the emergence of antimicrobial-resistant strains. Therefore, the present study evaluated the effectiveness of herbal extracts of E. arvense L., G. glabra L., P. granatum L. and S. barbatimam Mart. against clinical strains of Staphylococcus spp., S. mutans and Candida spp. In addition, the cytotoxic effects of the extract were investigated based on cell viability and cytokine production (interleukin $1 \beta[\mathrm{IL}-1 \beta]$ and tumor necrosis factor $\alpha$ [TNF$\alpha]$ ) in cultured mouse macrophages (RAW 264.7).

\section{Methods}

The study was approved by the Ethics Committee of the São José dos Campos Dental School, UNESP (protocol 008/2012-PA/CEP).

\section{Antimicrobial activity}

Dry powders of E. arvense L., G. glabra L., P. granatum L. and S. barbatimam Mart. were purchased from the Oficina de Ervas (Ribeirão Preto, São Paulo, Brazil) and the extracts were prepared in propylene glycol $(200 \mathrm{mg} / \mathrm{mL})$.

Nine clinical strains and reference strains (ATCC) of $S$. aureus (ATCC 6538), S. epidermidis (ATCC 12228), S. mutans (ATCC 35688), C. albicans (ATCC 18804), C. tropicalis (ATCC 13803) and C. glabrata (ATCC 90030) obtained from the Laboratory of Microbiology and Immunology, Institute of Science and Technology, were used. The clinical strains were identified after isolation from the oral cavity of patients with pulmonary tuberculosis. A total of 60 strains were tested.

Bacteria and yeast were cultured in brain-heart infusion (BHI - Himedia, Mumbai, Maharashtra, India) and Sabouraud-dextrose broth (Himedia), respectively, for $24 \mathrm{~h}$ at $37^{\circ} \mathrm{C}$. S. mutans was incubated under microaerophilic conditions $\left(5 \% \mathrm{CO}_{2}\right)$. The microbial suspensions were prepared in sterile saline $(0.9 \% \mathrm{NaCl})$ at a standard concentration of $5 \times 10^{5}$ cells $/ \mathrm{mL}$ for bacteria and $1 \times 10^{3}$ to $5 \times 10^{3}$ cells/mL for yeast.

The microdilution method was performed according to NCCLS guidelines [25,26], changes name to Clinical and Laboratory Standards Institute (CLSI). For this purpose, 10 dilutions of the plant extracts (100 to $0.19 \mathrm{mg} / \mathrm{mL}$ ) were prepared in Mueller-Hinton medium (Himedia) for bacteria and in RPMI 1640 medium (Himedia) plus MOPS buffer (Sigma Aldrich, St. Louis, Missouri, USA), pH $7.0 \pm$ 0.1 , for yeast. Next, $5 \mu \mathrm{L}$ of the bacterial suspension or $100 \mu \mathrm{L}$ of the yeast suspension was inoculated into each well of 96-well plates (TPP, Trasadingen, Schaffhausen, 
Switzerland) and the plates were incubated for $24 \mathrm{~h}$ at $37^{\circ} \mathrm{C}$ (under microaerophilic conditions for S. mutans).

After determination of the Minimum Inhibitory Concentration (MIC), $100 \mu \mathrm{L}$ of this concentration and one above and one below this concentration were seeded onto BHI or Sabouraud-dextrose agar plates to determine the Minimum Microbicidal Concentration (MMC) of the extracts. After $48 \mathrm{~h}$ of incubation, the MMC was determined on plates that showed no growth of colonies. The results are reported as the percentage of strains inhibited at each concentration of the plant extract.

\section{Cell culture}

Mouse macrophages (RAW 264.7) obtained from the Rio de Janeiro Cell Bank - Associação Técnico Científica Paul Ehrlich (APABCAM - Rio de Janeiro, RJ, Brazil) were cultured routinely in Dulbecco's Modified Eagle Medium (DMEM - LGC Biotechnology, Cotia, SP, Brazil) supplemented with $10 \%$ fetal bovine serum (FBS Gibco, USA) at $37^{\circ} \mathrm{C}$ in a $5 \% \mathrm{CO}_{2}$ atmosphere. Viable cells were counted by the Trypan blue $(0.5 \%$, Sigma-Aldrich, St. Louis, MO, USA) exclusion method.

\section{Cytotoxicity testing (MTT assay)}

For the experimental and positive control groups, $8 \times$ $10^{3}$ viable cells/well were seeded in 96-well plates (Nunc, Kamstrupvej, Roskilde, Denmark) and the plates were incubated for $24 \mathrm{~h}$ at $37^{\circ} \mathrm{C}$. Next, the cell cultures were exposed to $200 \mu \mathrm{L}$ of the serial dilutions of the plant extracts according to the concentrations obtained in the microbiological test and incubated for $24 \mathrm{~h}$. At the end of exposure, the cell culture medium was discarded and cell survival was determined by the MTT assay [MTT - (3(4,5-dimethylthiazol-2-yl)-2,5-diphenyltetrazolium bromide; Sigma-Aldrich].

The plates were washed with phosphate-buffered saline (PBS - Cultilab, Campinas, São Paulo, Brazil) and $100 \mu \mathrm{L}$ MTT solution $(0.5 \mathrm{mg} / \mathrm{mL}$ in PBS) was added to each well. After incubation for $1 \mathrm{~h}$, MTT solution was removed and $100 \mu \mathrm{L}$ dimethyl sulfoxide (DMSO - Sigma-Aldrich) was added to each well. The plates were incubated for $10 \mathrm{~min}$ and then shaken on a shaker for an additional $10 \mathrm{~min}$. Optical densities were measured in a multi-well spectrophotometer (Bio-Tek, Winooski, Vermont, USA) at $570 \mathrm{~nm}$. The optical density values obtained for cultures exposed to the extracts were normalized to untreated control cultures (corresponding to $100 \%$ ).

The results of the cytotoxicity tests were analyzed by ANOVA and the Tukey test $(\mathrm{P} \leq 0.05)$ using the BioEstat 5.0 software.

\section{Quantification of IL-1 $\beta$ and TNF- $\alpha$}

For analysis of cytokine production, $1 \times 10^{6}$ RAW264.7 cells were seeded in 24-well plates and incubated for
$24 \mathrm{~h}$ at $37^{\circ} \mathrm{C}$. Next, the cell cultures were exposed to concentrations of the plant extracts that were the most effective in the microbiological test. After incubation for $24 \mathrm{~h}$, the supernatant was collected from each well and frozen at $-18^{\circ} \mathrm{C}$.

The levels of IL-1 $\beta$ and TNF- $\alpha$ in the supernatants were determined by enzyme-linked immunosorbent assay (ELISA) using the DuoSet ELISA Development System for IL-1 $\beta$ (DY401) and TNF- $\alpha$ (DY410) ((R\&D Systems, Minneapolis, Minnesota, USA) according to manufacturer instructions. Optical densities were read on a microplate spectrophotometer at $450 \mathrm{~nm}$ and converted into IL-1 $\beta$ and TNF- $\alpha$ concentrations $(\mathrm{pg} / \mathrm{mL})$ using the GraphPad Prism 5.0 program.

The results were analyzed by ANOVA and the Tukey test $(\mathrm{P} \leq 0.05)$ using the BioEstat 5.0 software.

\section{Results}

The antimicrobial activity of the plant extracts is shown in Table 1 . The E. arvense L. extract, at a concentration of 50 $\mathrm{mg} / \mathrm{mL}$, eliminated $100 \%$ of S. aureus, S. epidermidis, C. albicans, C. tropicalis, and C. glabrata strains. At a concentration of $25 \mathrm{mg} / \mathrm{mL}$, this extract eliminated $100 \%$ of $S$. mutans. The MMC of the G. glabra L. extract was 100 $\mathrm{mg} / \mathrm{mL}$ for $S$. aureus, S. epidermidis and S. mutans, and $50 \mathrm{mg} / \mathrm{mL}$ for yeast (C. albicans, C. tropicalis, and $C$. glabrata). The $P$. granatum L. extract presented an MMC of $25 \mathrm{mg} / \mathrm{mL}$ for S. aureus and S. epidermidis, $12.5 \mathrm{mg} / \mathrm{mL}$ for $S$. mutans, and $50 \mathrm{mg} / \mathrm{mL}$ for yeast. The widest variation in MMC was observed for the S. barbatimam Mart. extract, with an MMC of $3.13 \mathrm{mg} / \mathrm{mL}$ for S. mutans, 12.5 $\mathrm{mg} / \mathrm{mL}$ for $S$. epidermidis, $25 \mathrm{mg} / \mathrm{mL}$ for $S$. aureus, and $50 \mathrm{mg} / \mathrm{mL}$ for yeasts.

Cytotoxicity of the plant extracts was evaluated in cultured macrophages by the MTT assay. The highest cell survival rates were observed for cultures treated with $G$. glabra L., P. granatum L. and S. barbatimam Mart. The group treated with the $E$. arvense L. extract exhibited the lowest survival rate $(<50 \%)$ (Table 2$)$.

Table 1 Values of the MMC $(\mathrm{mg} / \mathrm{mL})$ of plant extracts for all microorganisms evaluated

\begin{tabular}{lllll}
\hline Microorganism* & \multicolumn{4}{c}{ Plant extract } \\
\cline { 2 - 5 } & $\begin{array}{l}\text { E. } \\
\text { arvense }\end{array}$ & $\begin{array}{l}\text { G. } \\
\text { glabra }\end{array}$ & $\begin{array}{l}\text { L. } \\
\text { granatum }\end{array}$ & $\begin{array}{l}\text { S. barbatimam } \\
\text { Mart. }\end{array}$ \\
\hline S. aureus & 50 & 100 & 25 & 25 \\
S. epidermidis & 50 & 100 & 25 & 12.5 \\
S. mutans & 25 & 100 & 12.5 & 3.13 \\
C. albicans & 50 & 50 & 50 & 50 \\
C. tropicalis & 50 & 50 & 50 & 50 \\
C. glabrata & 50 & 50 & 50 & 50 \\
\hline
\end{tabular}

*Ten strains of each microbial species were evaluated. 
Table 2 Percentage of cell viability ( \pm SD) after treatment with the MMC of plant extracts

\begin{tabular}{lllll}
\hline $\begin{array}{l}\text { Concentration } \\
(\mathbf{m g} / \mathbf{m L})\end{array}$ & \multicolumn{4}{c}{ Plant extract } \\
\cline { 2 - 5 } & $\begin{array}{l}\text { E. } \\
\text { arvense L. }\end{array}$ & $\begin{array}{l}\text { G. } \\
\text { glabra } \text { L. }\end{array}$ & $\begin{array}{l}\text { P. } \\
\text { granatum L. }\end{array}$ & $\begin{array}{l}\text { S. barbatimam } \\
\text { Mart. }\end{array}$ \\
\hline 100 & - & $79 \pm 6.18^{\mathrm{B}}$ & - & - \\
50 & $48 \pm 5.29^{\mathrm{B}}$ & $52 \pm 2.96^{\mathrm{C}}$ & $76 \pm 3.10^{\mathrm{B}}$ & $86 \pm 4.05^{\mathrm{B}}$ \\
25 & $45 \pm 1.08^{\mathrm{B}}$ & - & $57 \pm 5.24^{\mathrm{C}}$ & $70 \pm 4.96^{\mathrm{C}}$ \\
12,5 & - & - & $57 \pm 3.70^{\mathrm{C}}$ & $65 \pm 4.91^{\mathrm{C}}$ \\
3,13 & - & - & - & $72 \pm 6.27^{\mathrm{C}}$ \\
Control & $100^{\mathrm{A}}$ & $100^{\mathrm{A}}$ & $100^{\mathrm{A}}$ & $100^{\mathrm{A}}$ \\
\hline
\end{tabular}

Different superscript letters indicate statistically significant differences $(P<0.05)$.

Analysis of cytokine production showed a significant increase of IL-1 $\beta$ production in cultures treated with the $P$. granatum L. and S. barbatimam Mart. extracts when compared to the control group. No difference in IL-1 $\beta$ production was observed between cultures treated with the E. arvense L. and G. glabra L. extracts and the control group (Table 3).

All extracts significantly reduced the production of TNF$\alpha$ when compared to the control group, with complete inhibition of TNF- $\alpha$ production in the $P$. granatum L.treated group (Table 3).

\section{Discussion}

The present study evaluated the antimicrobial activity of plant extracts not only against reference strains (ATCC), but also against clinical isolates since differences in antimicrobial susceptibility exist between the same species isolated from different patients as demonstrated by the present results. The four extracts exerted microbicidal activity against six microbial species. However, the MMC varied according to the extract and its concentration used and according to bacterial or fungal species studied.

The $S$. mutans isolates showed high sensitivity to the E. arvense L. extract, with a concentration of $25 \mathrm{mg} / \mathrm{mL}$ inhibiting the growth of all strains. At a concentration of

Table 3 Levels of IL-1 $\beta$ and TNF- $\alpha$ (mean \pm standard deviation, $\mathrm{pg} / \mathrm{mL}$ ) in macrophage culture supernatants after exposure to plant extracts $(100 \mathrm{mg} / \mathrm{mL}$ for G. glabra L. and $50 \mathrm{mg} / \mathrm{ml}$ for $E$. arvense L., $P$. granatum $L_{\text {. }}$ and S. barbatimam Mart.)

\begin{tabular}{lll}
\hline Plant extract & \multicolumn{2}{c}{ Cytokine production $(\mathbf{p g} / \mathbf{m L})$} \\
\cline { 2 - 3 } & IL-1 $\boldsymbol{\beta}$ & TNF-a \\
\hline E. arvense L. & $1.32 \pm 1.37^{\mathrm{A}}$ & $0.83 \pm 2.86^{\mathrm{B}}$ \\
G. glabra L. & $1.99 \pm 1.46^{\mathrm{A}}$ & $4.92 \pm 1.46^{\mathrm{B}}$ \\
P. granatum L. & $7.72 \pm 1.13^{\mathrm{C}}$ & $0.00^{\mathrm{B}}$ \\
S. barbatimam Mart. & $3.98 \pm 1.40^{\mathrm{B}}$ & $0.85 \pm 2.93^{\mathrm{B}}$ \\
Control & $2.20 \pm 2.11^{\mathrm{A}}$ & $41.96 \pm 10.53^{\mathrm{A}}$ \\
\hline
\end{tabular}

Different superscript letters indicate statistically significant differences $(P<0.05)$.
$50 \mathrm{mg} / \mathrm{mL}$, E. arvense L. was effective against all Staphylococcus spp. and Candida spp. isolates. The antimicrobial activity of $E$. arvense L. can be attributed to the presence of various compounds such as the phenolic monoterpene thymol, capable inhibit the growth of microorganisms $[8,27]$. It was reported that concentrations of E. arvense L. hydromethanolic extracts presented a dose-dependent activity in S. aureus, at $10-1000 \mathrm{mg} / \mathrm{mL}$, showing a total elimination at $1000 \mathrm{mg} / \mathrm{mL}$ [28]. According to Radulovic et al. [27] the essential oil of E. arvense L. also showed activity against $S$. aureus and $C$. albicans strains, in agreement with our study, yet it was effective against Gramnegative bacteria Klebsiella pneumoniae, Pseudomonas aeruginosa, Salmonella enteritidis, Escherichia coli, and against Aspergillus niger. In vitro tests also demonstrated the inhibitory effect of $E$. arvense L. hydroethanolic extract against Neisseria gonorrhoeae [29].

The G. glabra L. extract inhibited the growth of all bacterial strains studied at a concentration of $100 \mathrm{mg} / \mathrm{mL}$. In contrast, fungal growth was inhibited at a concentration of less than $50 \mathrm{mg} / \mathrm{mL}$, demonstrating that Candida spp. were more sensitive to the extract than the bacterial strains. Antifungal activity of this plant was attributed to the presence of glabridin, hispaglabridin B [30] and 18 $\beta$ glycyrrhetinic acid [9]. Glabridin exhibiting inhibitory activity against $C$. albicans strain and inhibited the growth of this yeast mutant strain resistant to amphotericin B, nystatin and clotrimazole [30]. This compound also showed inhibitory effect on the growth of $S$. aureus strains sensitive and resistant to methicillin, showing MIC at $12.5 \mathrm{mg} /$ $\mathrm{mL}$ [31]. The 18 $\beta$-glycyrrhetinic acid caused inhibitory effect for C. albicans at concentrations of 50 and $100 \mathrm{mg} /$ $\mathrm{mL}$ [9]. Clinical and reference strains of this yeast was also proven their susceptibility to the extract of G. glabra L. prepared in different solvents as ethanol, ethyl acetate, and hexane [32]. According to our study, Hwang et al. [33] also found the antibacterial extract G. glabra L regard to S. mutans. Statti et al. [34] collected G. glabra L. from different regions of Calabria, Italy, and verified an inhibitory effect on bacteria and fungi, and this biological activity varied due to differences in the chemical composition of this plant obtained from different sites.

The $P$. granatum L. extract completely inhibited the growth of S. mutans, Staphylococcus spp. and Candida spp. at concentrations of 12.5, 25 and $50 \mathrm{mg} / \mathrm{mL}$, respectively. Thus, $S$. mutans showed high sensitivity to the extract, whereas Candida spp. exhibited low sensitivity to $P$. granatum L., requiring higher concentrations for growth inhibition. Rosas-Piñon et al. [35] studying the medicinal plants from a Mexico region used by local people to treat dental diseases such as toothache, dental caries, periodontal disease and gingivitis, found the antimicrobial activity of 47 plant species on Porphyromonas gingivalis and S. mutans. According to our study, the authors 
verified that $S$. mutans was more sensitive to $P$. granatum L extract, compared to $P$. gingivalis, showing lower inhibitory concentrations of growth. Thus, it is believed that this higher sensitivity of streptococcal is related to its cell composition. Products based on P. granatum L., as commercial sauces and juices also showed antimicrobial activity against natural microbiota of vegetables such as lettuce, chives and parsley, as well as on $S$. aureus and E. coli that was inoculated on these plants [36]. Our results are in agreement with Abdollahzadeh et al. [37], which verified that $P$. granatum L. extract was effective on oral opportunistic pathogens such as $S$. aureus, $S$. epidermidis, S. mutans and C. albicans. Also, Fawole et al. [38] showed that P. granatum L. extract was effective on S. aureus, and this extract also presented antimicrobial activity against $K$. pneumoniae and E. coli. Some studies have also been proven the effectiveness of $P$. granatum L. against MRSA, Listeria monocytogenes, Bacillus subtilis, S. enteritidis and Yersinia enterocolitica [39]. The bactericidal activity of this plant is due to the presence of tannins and punicalagins $[40,41]$. A paste based on the extract of $P$. granatum L. [42] was produced and applied on wounds created in guinea pigs and their potential healing was confirmed with total regression of the wound in 20 days, and also effectively control the microbiota of the wound. In vitro tests have demonstrated the antimicrobial activity of this extract on S. aureus, P. aeruginosa, E. coli, K. pneumoniae, Salmonella anatum, S. typhimurium, S. pneumoniae, C. albicans, C. glabrata, and A. rubrum Trichopyton niger. Vasconcelos et al. [7] also used a gel based on P. granatum L. extract to control S. mutans, S. sanguis, S. mitis and C. albicans, alone or associated with each other, and it has shown inhibition of adhesion of these microorganisms on the glass surface. By inhibiting the adherence of $S$. mutans other species also have their adhesion impaired, since this streptococci fail to provide the support to anchor these pathogens; e.g., C. albicans on the tooth surface [43].

The $S$. barbatimam Mart. extract exerted microbicidal activity at different concentrations, which were $3.13 \mathrm{mg} /$ $\mathrm{mL}$ for S. mutans, $12.5 \mathrm{mg} / \mathrm{mL}$ for S. aureus, and 25 $\mathrm{mg} / \mathrm{mL}$ for S. epidermidis. However, only the concentration of $50 \mathrm{mg} / \mathrm{mL}$ was effective against the Candida species tested. The results of our study demonstrate that $S$. mutans was the most sensitive specie to $S$. barbatimam Mart. extract, and C. albicans was less sensitive, agreeing with the study by Pereira et al. [44], which the extract of Stryphnodendron spp. also had lower and higher MMC against $S$. mutans and C. albicans, respectively. The extract of Stryphnodendron spp. produced in aqueous and ethyl-acetate fractions showed significant antifungal activity against clinical isolates of C. albicans, C. parapsilosis and $C$. tropicalis, and revealed that the presence of tannins affected the integrity of the cell wall of Candida, a factor that contributes to decreased adhesion to host cells and germ-tube formation, besides affecting the budding process and stimulate phagocytosis [6].

The present study also analyzed the cytotoxicity of the $E$. arvense L., G. glabra L., P. granatum L. and S. barbatimam Mart extracts in macrophage cultures (RAW 264.7) using the most effective concentrations obtained in the microbiological test. Except for P. granatum L., there are no studies in the literature investigating the cytotoxicity of these plants by the methods used here. After exposure for 24 h to G. glabra L., at concentrations of 100 and $50 \mathrm{mg} / \mathrm{mL}$, reduced cell survival by $79 \%( \pm 6.18)$ and $52 \%$ ( \pm 2.96), respectively. The viability of cells treated with P. granatum L. at a concentration of $50 \mathrm{mg} / \mathrm{mL}$ was $76 \%$ ( \pm 3.10 ), whereas the percentage of surviving cells was $57 \%$ $( \pm 5.24)$ and $57 \%( \pm 3.70)$ at concentrations of 25 and 12.5 $\mathrm{mg} / \mathrm{mL}$, respectively. The percentage of surviving cells was $86 \%$ ( \pm 4.05$), 70 \%( \pm 4.96), 65 \%( \pm 4.91)$, and $72 \%( \pm 6.27)$ for macrophages treated with S. barbatimam Mart. at concentrations of $50,25,12.5$ and $3.13 \mathrm{mg} / \mathrm{mL}$, respectively. Cell viability was less than $50 \%$ only in the groups treated with E. arvense L., i.e., $48 \%( \pm 5.29)$ at $50 \mathrm{mg} / \mathrm{mL}$ and $45 \%$ $( \pm 1.08)$ at $25 \mathrm{mg} / \mathrm{mL}$. It has been demonstrated reduction in cell viability after $24 \mathrm{~h}$ exposure to antimicrobials used in endodontic therapy such as ciprofloxacin hydrochloride, clindamycin hydrochloride, and metronidazole, with these drugs, showing dose-dependent cytotoxicity [45]. In the present study, cell viability was significantly higher in the groups treated with higher concentrations of G. glabra L., P. granatum L. and S. barbatimam Mart. when compared to the groups treated with lower concentrations.

The cytotoxicity of the plant extracts was also investigated by quantifying the production of IL-1 $\beta$ and TNF- $\alpha$ in cell cultures (RAW 264.7) after 24-h exposure to concentrations of the extracts that were most effective against the microorganisms tested. No significant difference in the production of IL-1 $\beta$ was observed between cultures treated with $E$. arvense L. $(1.32 \pm 1.37 \mathrm{pg} / \mathrm{mL})$ and G. glabra L. $(1.99 \pm 1.46 \mathrm{pg} / \mathrm{mL})$ and the control group $(2.20 \pm 2.11$ $\mathrm{pg} / \mathrm{mL}$ ). In contrast, production of this cytokine was significantly higher in cultures treated with $S$. barbatimam Mart. (3.98 $\pm 1.40 \mathrm{pg} / \mathrm{mL})$ and P. granatum L. (7.72 \pm 1.13 $\mathrm{pg} / \mathrm{mL}$ ). The production of TNF- $\alpha$ was significantly lower in cultures treated with $E$. arvense L. $(0.83 \pm 2.86 \mathrm{pg} / \mathrm{mL})$, G. glabra L. (4.92 $\pm 1.46 \mathrm{pg} / \mathrm{mL})$ and S. barbatimam Mart. $(0.85 \pm 2.93 \mathrm{pg} / \mathrm{mL})$ when compared to the group not stimulated with the extracts $(41.96 \pm 10.53 \mathrm{pg} / \mathrm{mL})$. The P. granatum L. extract completely inhibited the synthesis of TNF- $\alpha$. Thus, it was observed that the basal levels of TNF- $\alpha$ were higher than those of IL-1 $\beta$. This behavior also was shown in other studies $[46,47]$.

The study of the cytotoxicity and antimicrobial activity of natural products such as plant extracts is important for the clinical application of these compounds in different areas of health care. For example, in dentistry, 
mouthwashes, root canal irrigants, intracanal medications and even toothpastes with antimicrobial activity could be developed that are safe for use in humans. However, animal studies and subsequent clinical trials are needed to confirm the safety of these products.

\section{Conclusion}

In conclusion, the E. arvense L., G. glabra L. P. granatum L. and S. barbatimam Mart. extracts exerted microbicidal activity against all Staphylococcus spp., S. mutans and Candida spp. strains tested. The G. glabra extract exhibited least cytotoxicity and the $E$. arvense extract was the most cytotoxic.

\begin{abstract}
Abbreviations
${ }^{\circ} \mathrm{C}$ : Degrees celsius; ANOVA: Analysis of variance; ATCC: American Type Culture Collection; BHI: Brain-heart infusion; CLSI: Clinical and Laboratory Standards Institute; $\mathrm{CO}_{2}$ : Carbon dioxide; DMEM: Dulbecco's Modified Eagle Medium; DMSO: Dimethyl sulfoxide; ELISA: Enzyme-linked immunosorbent assay; FBS: Fetal bovine serum; h: Hour(s); IL-1 1 : Interleukin 1-beta; mg/mL: Milligram per milliliter; MIC: Minimum Inhibitory Concentration; MMC: Minimum Microbicidal Concentration; MOPS: 3-(N-morpholino) propanesulfonic acid; MRSA: Methicillin-resistant S. aureus; MTT: (3-(4,5-dimethylthiazol-2-yl)-2,5-diphenyltetrazolium bromide; NaCl: Sodium chloride; NCCLS: National Committee for Clinical Laboratory Standards; nm: Nanometers; PBS: Phosphate-buffered saline; pg/mL: Picograms per milliliter; RAW 264.7: Cell line of mouse macrophages; RPMI: Medium developed by Moore et al. in Roswell Park Memorial Institute; TNF-a: Tumor necrosis factor alpha.
\end{abstract}

\section{Competing interests}

No conflict of interests for this study with any person or institution.

\section{Authors' contributions}

JRO: conception, design of the experiments, interpretation of data, redaction of the manuscript and attainment of the tables. VCC: design of the experiments. PGFV: conception, design of the experiments. SEAC: redaction and review of the manuscript. CATC: conception and redaction of the manuscript. AOCJ: conception, interpretation of data and redaction of the manuscript. LDO: conception, interpretation of data, critical analysis and redaction of the manuscript. All authors read and approved the final manuscript.

\section{Author details}

'Department of Biosciences and Oral Diagnosis, Laboratory of Microbiology and Immunology, Institute of Science and Technology, Univ Estadual Paulista/UNESP, Av. Engenheiro Francisco José Longo, 777 - Jardim São Dimas, São José dos Campos, SP, Brazil. ${ }^{2}$ Department of Biosciences and Oral Diagnosis, Laboratory of Biochemistry and Pharmacology, Institute of Science and Technology, Univ Estadual Paulista/UNESP, São José dos Campos, SP, Brazil. ${ }^{3}$ Department of Restorative Dentistry, Institute of Science and Technology, Univ Estadual Paulista/UNESP, São José dos Campos, SP, Brazil.

Received: 11 February 2013 Accepted: 13 August 2013

Published: 15 August 2013

\section{References}

1. Calixto JB: Twenty-five years of research on medicinal plants in Latin America: a personal view. J Ethnopharmacol 2005, 100:131-134.

2. Holetz FB, Ueda TN, Dias FBP: Biological effects of extracts obtained from stryphnodendron adstringens on herpetomonas samuelpessoai. Mem Inst Oswaldo Cruz 2005, 100:397-401.

3. Meléndez PA, Capriles VA: Antibacterial properties of tropical plants from Puerto Rico. Phytomed 2006, 13:272-276.

4. Haidari M, Ali M, III SWC, Madjid M: Pomegranate (punica granatum) purified polyphenol extract inhibits influenza virus and has a synergistic effect with oseltamivir. Phytomedicine 2009, 16:1127-1136.
5. Jurenka J: Therapeutic applications of pomegranate (punica granatum L.): a review. Altern Med Rev 2008, 13(2):128-144.

6. Ishida K, Mello JCP, Cortez DAG, Dias FBP, Nakamura TU, Nakamura CV: Influence of tannins from stryphnodendron adstringens on growth and virulence factors of Candida albicans. J Antimicrob Chemother 2006, 58:942-949.

7. Vasconcelos LCS, Sampaio FC, Sampaio MCC, Pereira MSV, Higino JS, Peixoto MHP: Minimum inhibotory concentration of adherence of punica granatum Linn (pomegranate) gel against S. Mutans, S. Mitis and C. Albicans. Braz Dent J 2006, 17(3):223-227.

8. Milovanovic V, Radulovic N, Todorovic Z, Stankovic M, Stojanovic G: Antioxidant, antimicrobial and genotoxicity screening of hydro-alcoholic extracts of five Serbian equisetum species. Plant Foods Hum Nutr 2007, 62:113-119.

9. Pellati D, Fiore C, Armanini D, Rassu M, Bertoloni G: In vitro effects of glycyrrhetinic acid on the growth of clinical isolates of Candida albicans. Phytother Res 2009, 23:572-574.

10. Santos VR, Gomes RT, Oliveira RR, Cortés ME, Brandão MGL: Susceptibility of oral pathogenic microorganisms to aqueous and ethanolic extracts of stryphnodendron adstringens (barbatimão). Int J Dent 2009, 8(1):1-5.

11. Wittschier N, Faller G, Hensel A: Aqueous extracts and polysaccharides from liquorice roots (glycyrrhiza glabra L.) inhibit adhesion of helicobacter pylori to human gastric mucosa. J Ethnopharmacol 2009, 125:218-223.

12. Smith AJ, Jackson MS, Bagg J: The ecology of staphylococcus species in the oral cavity. J Med Microbiol 2001, 50(11):940-946.

13. Stamatis G, Kyriazopoulos P, Golegou S, Basayiannis A, Skaltsas S, Skaltsa H: In vitro anti-helicobacter pylori activity of Greek herbal medicines. J Ethnopharmacol 2003, 88:175-179.

14. Filoche SK, Soma K, Sissons CH: Antimicrobial effects of essential oils in combination with chlorhexidine digluconate. Oral Microbiol Immunol 2005, 20:221-225.

15. Deurenberg RH, Stobberingh EE: The evolution of staphylococcus aureus. Infect Genet Evol 2008, 8:747-763.

16. An YH, Friedman RJ: Handbook of bacterial adhesion: principles, methods and applications. Totowa: Humana Press Inc; 2000.

17. Davey ME, OToole GA: Microbial biofilms: from ecology to molecular genetics. Microbiol Mol Biol Rev 2000, 64(4):847-867.

18. Zanin ICJ, Lobo MM, Rodrigues LK, Pimenta LA, Hofling JF, Gonçalves RB: Photosensitization of in vitro biofilms by toluidine blue $\mathrm{O}$ combined with light-emitting diode. Eur J Oral Sci 2006, 114(1):64-69.

19. Ooshima T, Osaka Y, Sasaki H, Osawa K, Yasuda H, Matsumura M, Sobue S, Matsumoto M: Caries inhibitory activity of cacao bean husk extract in vitro and animals experiments. Arch Oral Biol 2000, 45(8):639-645.

20. Barbieri DSV, Vicente VA, Fraiz FC, Lavoranti OJ, Svidzinski TIE, Pinheiro RL: Analysis of the in vitro adherence of streptococcus mutans and Candida albicans. Braz J Microbiol 2007, 38:624-631.

21. Kojic EM, Darouiche RO: Candida infections of medical devices. Clin Microbiol Rev 2004, 17:255-267.

22. Uppuluri P, Dinakaran H, Thomas DP, Chaturvedi AK, Lopez-ribot J Characteristics of Candida albicans biofilms grown in a synthetic urine medium. J Clin Microbiol 2009, 47:4078-4083.

23. Chandra J, Kuhn DM, Mukherjee PK, Hoyer LL, Mccormick T, Ghannoum MA: Biofilm formation by the fugal pathogen Candida albicans: development architecture and drug resistance. J Bacteriol 2001, 183(18):5385-5394.

24. Ramage $G$, Mowat $E$, Jones $B$ : Our current understanding of fungal biofilms. Crit Rev Microbiol 2009, 35:340-355.

25. NCCLS (National Committee for Clinical Laboratory Standards): Reference method for broth dilution antifungal susceptibility testing of yeasts. Approved standard - second edition. M27-A2. Wayne, PA, USA; 2002. ISBN 1-56238-469-4.

26. NCCLS (National Committee for Clinical Laboratory Standards): Methods for dilution antimicrobial susceptibility tests for bacteria that grow aerobically. Approved standard - sixth edition. M7-A6. Wayne, PA, USA; 2003. ISBN 156238-486-4

27. Radulovic N, Stojanovic G, Palic R: Composition and antimicrobial activity of equisetum arvense L. Essential oil. Phytother Res 2006, 20:85-88.

28. Pereira CB, Gomes PS, Costa-Rodrigues J, Almeida PR, Vieira L, Ferraz MP, Lopes MA, Fernandes MH: Equisetum arvense hydromethanolic extracts in bone tissue regeneration: in vitro osteoblastic modulation and antibacterial activity. Cell Prolif 2012, 45:386-396.

29. Cybulska P, Thakur SD, Foster BC, Scott IM, Leduc RI, Arnason JT, Dillon JA: Extracts of Canadian first nations medicinal plants, used as natural 
products, inhibit neisseria gonorrhoeae isolates with different antibiotic resistance profiles. Sex Transm Dis 2011, 38:667-671.

30. Fatima A, Gupta VK, Luqman S, Negi AS, Kumar JK, Shanker K, Saikia D, Srivastava S, Darokar MP, Khanuja SP: Antifungal activity of glycyrrhiza glabra extracts and its active constituent glabridin. Phytother Res 2009, 23:1190-1193.

31. Fukai T, Marumo A, Kaitou K, Kanda T, Terada S, Nomura T: Antimicrobial activity of licorice flavonoids against methicillin-resistant staphylococcus aureus. Fitoterapia 2002, 6:536-539.

32. Motsei ML, Lindsey KL, van Staden J, Jäger AK: Screening of traditionally used south African plants for antifungal activity against Candida albicans.J Jthnopharmacol 2003, 86:235-241.

33. Hwang JK, Shim JS, Chung JY: Anticariogenic activity of some tropical medicinal plants against streptococcus mutans. Fitoterapia 2004, 75:596-598.

34. Statti GA, Tundis R, Sacchetti G, Muzzoli M, Bianchi A, Menichini F: Variability in the content of active constituents and biological activity of glycyrrhiza glabra. Fitoterapia 2004, 75:371-374.

35. Rosas-Piñón Y, Mejía A, Díaz-Ruiz G, Aguilar Ml, Sánchez-Nieto S, Rivero-Cruz JF: Ethnobotanical survey and antibacterial activity of plants used in the altiplane region of Mexico for the treatment of oral cavity infections. J Ethnopharmacol 2012, 141:860-865.

36. Karabiyikli S, Kisla D: Inhibitory effect of sour pomegranate sauces on some green vegetables and kisir. Int J Food Microbiol 2012, 155:211-216.

37. Abdollahzadeh S, Mashouf R, Mortazavi H, Moghaddam M, Roozbahani N, Vahedi M: Antibacterial and antifungal activities of punica granatum peel extracts against oral pathogens. J Dent (Tehran) 2011, 8:1-6.

38. Fawole OA, Makunga NP, Opara UL: Antibacterial, antioxidant and tyrosinase-inhibition activities of pomegranate fruit peel methanolic extract. BMC Complement Altern Med 2012, 12:200.

39. Al-Zorey NS: Antimicrobial activity of pomegranate (punica granatum L.) fruit peels. Int J Food Microbiol 2009, 134:244-248.

40. Voravuthikunchai S, Sririrak T, Limsuwan S, Supawita T, lida T, Honda T: Inhibitory effects of active compounds from punica granatum pericarp on verocytotoxin production by enterohemorrhagic Escherichia coli 0157: H7. J Health Sci 2005, 51:590-596.

41. Machado TB, Leal ICR, Amaral ACF, Santos KRN, Silva MG, Kuster RM: Antimicrobial ellagitannin of punica granatum fruits. J Braz Chem Soc 2002, 13(5):606-610.

42. Hayouni EA, Miled K, Boubaker S, Bellasfar Z, Abedrabba M, Iwaski H, Oku H, Matsui T, Limam F, Hamdi M: Hydroalcoholic extract based-ointment from punica granatum L. Peels with enhanced in vivo healing potential on dermal wounds. Phytomedicine 2011, 18(11):976-984.

43. Nikawa H, Yamashiro H, Makihira S, Nishimura M, Egusa H, Furukawa M, Setijanto D, Hamada T: In vitro cariogenic potential of Candida albicans. Mycoses 2003, 46:471-478.

44. Pereira EMR, Gomes RT, Freire NR, Aguiar EG, Brandão MGL, Santos VR: In vitro antimicrobial activity of Brazilian medicinal plant extracts against pathogenic microorganisms of interest to dentistry. Planta Med 2011, 77:401-402

45. Ferreira MB, Myiagi S, Nogales CG, Campos MS, Lage-Marques JL: Time and concentration-dependent cytotoxicity of antibiotics used in endodontic therapy. J Appl Oral Sci 2010, 18(3):259-263.

46. Kim IS, Ko HM, Koppula S, Kim BW, Choi DK: Protective effect of chrysanthemum indicum linne against 1-methyl-4-phenylpridinium ion and lipopolysaccharide-induced cytotoxicity in cellular model of Parkinson's disease. Food Chem Toxicol 2011, 49:963-973.

47. Sheeja K, Kuttan G: Andrographis paniculata downregulates proinflammatory cytokine production and augments cell mediated immune response in metastatic tumor-bearing mice. Asian Pacific J Cancer Prev 2010, 11:723-729.

doi:10.1186/1472-6882-13-208

Cite this article as: de Oliveira et al: Cytotoxicity of Brazilian plant extracts against oral microorganisms of interest to dentistry. $B M C$ Complementary and Alternative Medicine 2013 13:208.

\section{Submit your next manuscript to BioMed Central and take full advantage of:}

- Convenient online submission

- Thorough peer review

- No space constraints or color figure charges

- Immediate publication on acceptance

- Inclusion in PubMed, CAS, Scopus and Google Scholar

- Research which is freely available for redistribution

Submit your manuscript at www.biomedcentral.com/submit
C Biomed Central 